\title{
BIOINSECTICIDE POTENTIAL OF Curcuma zedoaria RHIZOME
} ESSENTIAL OIL

\section{POTENCIAL BIOINSETICIDA DO ÓLEO ESSENCIAL DOS RIZOMAS DE Curcuma zedoaria}

\author{
Herika Line Marko de OLIVEIRA ${ }^{1}$; Wanessa de Campos BORTOLUCCI ${ }^{1}$; \\ Eloísa Schneider SILVA ${ }^{1}$; Caio Franco de Araújo Almeida CAMPOS ${ }^{2}$; \\ José Eduardo GONÇALVES ${ }^{2,3}$; Ranulfo PIAU JÚNIOR ${ }^{4}$; Giani Andréa LINDE ${ }^{1}$; \\ Zilda Cristiani GAZIM ${ }^{1}$
}

1. Programa de Pós-Graduação em Biotecnologia Aplicada à Agricultura. Universidade Paranaense - Unipar, Umuarama - Pr; 2. Programa de Pós-graduação em Tecnologias Limpas, Centro Universitário de Maringá - UniCesumar, Maringá, PR; 3. Instituto Cesumar de Ciência, Tecnologia e Inovação - ICETI, Maringá-PR; 4. Programa de Pós-Graduação em Ciência Animal da Universidade Paranaense - Unipar, Umuarama, PR. cristianigazim@prof.unipar.br

\begin{abstract}
In this study the potential bioinseticide of the essential oil (OE) extracted from the rhizomes of the species Curcuma zedoaria (Zingiberaceae) was evaluated. The rhizomes were collected during dormancy (winter) and budding (summer). The EO was obtained by hydrodistillation ( $2 \mathrm{~h}$ ) and identified by GC/MS. In addition, a multivariate exploratory analysis was done to determine the analysis of the major compounds (PCA). The EO yield in dormancy was $0.61 \pm 0.07(\%)$ and in budding $0.55 \pm$ $0.08(\%)$. The bioassays on Aedes aegypti larvae and pupae were done by immersion test at different EO concentrations which ranged from 500.00 to $0.003 \mathrm{mg} \mathrm{mL}^{-1}(\mathrm{v} / \mathrm{v})$. The results on the larvae and pupae indicated $\mathrm{LC}_{99.9}$ of $\left(0.01\right.$ and $\left.1.38 \mathrm{mg} \mathrm{mL}^{-1}\right)$ for EO in dormancy, and $\left(0.08\right.$ and $\left.2.63 \mathrm{mg} \mathrm{mL}^{-1}\right)$ for EO during budding, respectively. The action mechanism of EOs in both periods was determined by autobiographic method evaluating the inhibitory potential on the acetylcholinesterase enzyme, indicating greater inhibition of the $\mathrm{EO}$ enzyme during dormancy $\left(0.039 \mathrm{mg} \mathrm{mL}^{-1}\right)$ when compared to the EO during budding $\left(0.156 \mathrm{mg} \mathrm{mL}^{-1}\right)$. The projection representation of the EO chemical classes in both evaluated periods indicated that oxygenated sesquiterpenes are the major compound class (46.99\% in dormancy) and (43.59\% in budding). The projection of major chemical compounds of EOs presented three compounds with greater mass flow distancing: epicurzerenone $(18.20 \%$ and $12.10 \%)$; 1.8 cineole $(15.76 \%$ and $12.10 \%)$ and $\beta$-elemene (4.43 and $0.01 \%)$ that are found in greater amounts in the dormancy EO when compared to budding, respectively. These results corroborate with the greater potential on Ae. aegypti larvae and pupae found for the dormancy EO. The results are promising because they show in which vegetative cycle phase $C$. zedoaria $\mathrm{EO}$ presents greater bioinsecticide potential.
\end{abstract}

KEYWORDS: Aedes aegypti. Anticholinesterase. 1,8 Cineole. Epicurzerenone. $\beta$-Elemene. Lethal concentration (LC).

ABBREVIATIONS: CG/MS gas chromatography coupled to mass spectrometer; LC lethal concentration; $\mathrm{LC}_{99.9}$ lethal concentration to eliminate $99.9 \%$ of larvae and pupa; EO essential oil.

\section{INTRODUCTION}

The species Aedes aegypti L. is the main vector transmitting Dengue, Chikungunya fever and Zika virus, which are responsible for significant human morbidity and mortality in a lot of countries, (BRASIL, 2015; WORLD HEALTH ORGANIZATION (WHO), 2016).

According to the epidemiologic report of the Health Ministry- from December 31, 2017 to March 10, 2018) - 51,980 cases of dengue, 12,261 cases of Chikungunya fever were reported, and in 2018 there must have been 1,174 probable cases of fever by Zika virus (BRASIL, 2018). In Brazil, the high incidence of these transmitting insects is due to the accelerated and disorderly urbanization process as well as the climatic and social conditions that favor their quick proliferation (OLIVEIRA; BIAZOTO, 2012; BUSATO et al., 2014).

The strategies to eradicate Ae. aegypti consist of the application of synthetic insecticides, mainly organophosphates and pyrethroids (BRAGA; VALLE, 2007). However, the utilization of these insecticides must be careful to avoid slowing down the development 
Bioinsecticide potential of...

of resistance to them (SMITH; KASAI; SCOTT, 2016), toxicity to humans as well as the impact that they cause to biodiversity (NICOLAU, 2013). Therefore, research studies utilizing biomolecules such as plant essential oils have been done (COSMOSKI et al., 2015) because these chemical structural groupings of these compounds or their combination can have, and also intensify, the larvicidal potential (SANTOS et al., 2010).

Considering this, the evaluated plant, Curcuma zedoaria (Zingiberaceae), is an exotic plant from Southern and southeastern Asia, which is well-adapted to the Southern region of Brazil, especially the northeastern region of Paraná state. Popularly known as zedoaria, vick and fake saffron, this species has been studied due to its therapeutic potential with several scientific results that confirm its traditional and popular medicinal use (LORENZI; 2002).

Its cultivation is easy and its rhizomes are rich in essential oil, mainly consisting of pinene, camphene, cineol, camphor and borneol (GUENTHER, 1950). However, this composition varies and is influenced by the plant vegetative phase and abiotic factors such as radiation, temperature, rainfall, winds, altitude, soil and cultivation implementation location (MORAIS, 2000; GOUINGUENÉ; TURLINGS, 2002). Research studies on its EO larvicidal potential are scarce and, therefore, caused our research group to deepen the investigations on the probable action against Ae. aegypti larvae and pupae.

Thus, this study aimed to evaluate the larvicidal potential of Curcuma zedoaria essential oil obtained in budding and dormancy periods against Ae. aegypti larvae and pupae.

\section{MATERIAL AND METHODS}

\section{Botanical identification and vegetal material preparation}

The cultivation of Curcuma zedoaria is found in the Medicinal Garden of the Paranaense University - Umuarama - PR. An exsiccata is deposited in the Educational Herbarium of Paranaense University - HEUP, under the registration number 2400. The botanical identification was done by Prof. Dr. Ezilda Jacomassi. This species is registered in the National System for the Management of Genetic Heritage and Associated Traditional Knowledge (SisGen) under the registration number ACFC9FF
OLIVEIRA, H. L. M. et al.

The vegetal material was dried, powdered and submitted to hydrodistillation process for two hours. The oil was withdrawn with a Pasteur pipette, filtered with $\mathrm{Na}_{2} \mathrm{SO}_{4}$ and stored at $-10^{\circ} \mathrm{C}$ (LAI et al., 2004).

\section{Chemical composition analysis of Curcuma zedoaria essential oil}

The chemical composition analysis was done using a gas chromatographer (Agilent 7890 B) coupled to mass spectrometer (Agilent 5977 A) equipped with an Agilent HP-5MS (30m x $0.250 \mathrm{~mm} \times 0.25 \mathrm{~m} \mu$ ) under the following conditions: injector temperature at $250^{\circ} \mathrm{C}$, injection volume $1 \mathrm{~mL}$ at a $1: 2$ rate (splitless mode), initial temperature of the column at $80^{\circ} \mathrm{C}$ with gradual heating until $260^{\circ} \mathrm{C}$ and a ramp of $4^{\circ} \mathrm{C} / \mathrm{min}$. The carrier gas (helium) flow was fixed at $1 \mathrm{~mL} / \mathrm{min}$. The transfer line temperatures and quadrupole ion sources were 250,230, and $150^{\circ} \mathrm{C}$, respectively. The mass spectra were obtained in a $40-500(\mathrm{~m} / \mathrm{z})$ interval provided by scanning with solvent permanence time of $3 \mathrm{~min}$. The compounds were identified by comparing their retention indices (RI) obtained from a series of n-alkanes (C8-C25) (LAI et al., 2004). Moreover, EI-mass spectra were compared to the spectra obtained from Wiley's Spectral Library 275L, and according to the literature (ADAMS, 2012).

\section{Major Compound Analysis (PCA)}

Complementarily, a multi-varied exploratory analysis was also done to determine the main compound analysis (PCA) which allowed the evaluation of the major chemical compounds and chemical class of all compounds found in the essential oil obtained in three analyzed periods (vegetative, flowering and fructification). The analysis result was graphically presented (Biplot), helping the characterization of the analyzed variable groups (MOITA NETO; MOITA, 1998).

For each sample of essential oil obtained during these three periods (vegetative, flowering and fructification), the identified major chemical compounds and their respective chemical classes, as well as the area amount in (\%) (Table 1), were plotted in Excel spreadsheets. These data were transformed in orthogonal latent variables called major components that are linear combinations of original variables created with the eigenvalues of the data covariance matrix (HAIR, 2005).

Kaiser's criterion was utilized to choose the main components. An eigenvalue preserves 
Bioinsecticide potential of...

the relevant information when it is greater than the unit. This analysis was carried out in two ways: the former contained only data referring to the chemical composition of the major compounds obtained in the three periods, and the latter analyzed the grouped chemical classes to which those compounds belong to. Both analyses were done utilizing Statistica 7 program (STATSOFT, 2001).

\section{Larvicidal activity against Aedes aegypti}

The larvicidal activity was done by Larval Immersion Test (LIT) against Aedes aegypti L. larvae and pupae from the Center for Vector transmitted Endemics - Secretary of Sanitary Surveillance of Umuarama, PR. The EO was tested at different concentrations: 500, 400, $300,200,100,50,25,12.5,6.25,3.125,1.562$, $0.781,0.390,0.195,0.097,0.048,0.024,0.012$, $0.006,0.003 \mathrm{mg} \mathrm{mL}^{-1}(\mathrm{v} / \mathrm{v})$, diluted in an aqueous polysorbate 80 solution at $2.0 \%$. Five third-stage Ae. aegypti larvae and five pupae were separated using a Pasteur pipette and placed in assay tubes containing $1.00 \mathrm{~mL}$ of different concentrations of EO (COSTA et al., 2005; CAVALCA; LOLIS BONATO, 2010). For the negative control, an aqueous polysorbate 80 solution at $2 \%$ was utilized whereas for the positive control, a commercial Temephós ${ }^{\circledR}$ solution at a concentration of $400 \mathrm{mg} \mathrm{L}^{-1}$ was used (CAMARGO et al., 1998). The larvae were exposed to EO at different concentrations for 24 hours (CARVALHO et al., 2003). They were considered dead when presented absence of movements and were irresponsive to stimuli (CAVALCA; LOLIS; BONATO, 2010). The data on the number of live and dead larvae and pupae were found through an average of three replications for each one of the tested concentrations.

\section{Anticholinesterase activity of essential oil}

The anticholinesterase activity was determined by the bioautographic method described by Marston et al. (2002) with modifications (YANG et al., 2009). The essential oil of $C$. zedoaria rhizome was tested starting from the initial concentration of $10,5,2.5,1.25$, $0.625,0.3125,0.1562,0.078,0.039,0.019 \mathrm{mg}$ $\mathrm{mL}^{-1}$, diluted in methanol. The samples were plotted in aluminum chromo plates $(10 \times 10 \mathrm{~cm}$,
OLIVEIRA, H. L. M. et al.

0.2 mm-thick 60 F254 silica gel). After plotting, the plates were dried and sprayed with an acetylcholinesterase enzyme solution in buffer solution; next, they were sprayed with an $\alpha$-naftyl acetate solution. The plates were kept at $37{ }^{\circ} \mathrm{C}$ for 20 minutes. After this period, the chromo plates were sprayed with Fast Blue B salt colorimetric reagent, resulting in a purple color surface. The anticholinesterase activity of $C$. zedoaria rhizome EO was determined by the emergence of white stains after 10 minutes, showing the inhibitory action of the evaluated concentrations on the enzyme activity, contrasting with the purple color of the colorimetric reagent (COLLINS et al., 1997) like the positive standard of the larvicide (Temephós ${ }^{\circledR}$.

\section{Statistical analysis}

The experiments were done in triplicate and the mortality percentage (\%) of Ae. aegypti larvae was obtained by calculating the mean \pm standard deviation and coefficient variation utilizing Microsoft Excel $^{\circledR}$ program $\left(\right.$ Excel $^{\circledR}$ Version 2010). The values of Lethal Concentration $\left(\mathrm{LC}_{50}\right.$ and $\left.\mathrm{LC}_{99.9}\right)$ and their respective confidence intervals (CI) were calculated by Probitos analysis (ED 50 Plus version 1.0). The obtained data were submitted to analysis of variance (ANOVA) and the differences between the averages were determined by Scott-Knott's test $(\mathrm{p} \leq 0.05)$.

\section{RESULTS AND DISCUSSION}

The essential oil of Curcuma zedoaria rhizome has lilac coloring, with greater yield in the dormancy period $(0.61 \pm 0.07 \%)$ compared to the budding period $(0.55 \pm 0.08 \%)$. This difference in the yield is justified because in this period the buds are in the peak of their maturation (DING; NILSSON, 2016), and the found values are in accordance with Angel et al. (2014), who found yields ranging from 0.38 to 1.4 (\%) for C. zedoaria species.

The chemical identification of the essential oil obtained during the dormancy and budding periods was done by a gas chromatographer coupled to a mass spectrometer and whose results are shown in Table 1 and Figures 1 and 2. 
Table 1. Chemical composition of essential oils obtained from Curcuma zedoaria rhizomes during dormancy and vegetative periods.

\begin{tabular}{|c|c|c|c|c|c|c|c|c|c|c|}
\hline \multirow[t]{2}{*}{ Peak } & \multirow[t]{2}{*}{${ }^{\mathrm{a} C o m p o u n d}$} & \multirow[t]{2}{*}{${ }^{\mathbf{b}} \mathbf{R I}$} & Dormancy & Budding & Peak & ${ }^{\mathrm{a} C o m p o u n d}$ & ${ }^{\mathbf{b}} \mathbf{R I}$ & Dormancy & Budding & $\begin{array}{l}\text { Identification } \\
\text { Methods }\end{array}$ \\
\hline & & & \multicolumn{4}{|c|}{ Relative Area (\%) } & \multicolumn{4}{|c|}{ Relative Area (\%) } \\
\hline 1 & Heptanol & 880 & $\mathrm{t}$ & 0.03 & 20 & trans-sabinene & 1068 & 0.33 & 0.22 & $a, b, c$ \\
\hline 2 & Tricyclene & 899 & 0.06 & - & 21 & $\beta$-thujone & 1079 & - & 0.53 & $a, b, c$ \\
\hline 3 & $\alpha$ - thujene & 905 & 0.05 & 0.08 & 22 & $\alpha$ - thujone & 1088 & $\mathrm{t}$ & 0.04 & $a, b, c$ \\
\hline 4 & $\alpha$-pinene & 907 & 0.85 & 0.06 & 23 & cis-limonene oxide & 1095 & 0.05 & - & $a, b, c$ \\
\hline 5 & Fenchene & 913 & - & 0.82 & 24 & cis- vebenol & 1115 & $\mathrm{t}$ & 0.07 & $a, b, c$ \\
\hline 6 & Camphene & 929 & 1.39 & 1.38 & 25 & Camphor & 1117 & 5.61 & 5.83 & $a, b, c$ \\
\hline 7 & Sabinene & 956 & 0.27 & - & 26 & Camphene hydrate & 1118 & 0.06 & $\mathrm{t}$ & $a, b, c$ \\
\hline 8 & $\beta$-pinene & 958 & 1.55 & 1.79 & 27 & Isoborneol & 1126 & 1.51 & 1.83 & $a, b, c$ \\
\hline 9 & Myrcene & 973 & 0.41 & 0.50 & 28 & Pinocarvone & 1130 & $\mathrm{t}$ & 0.05 & $\mathrm{a}, \mathrm{b}, \mathrm{c}$ \\
\hline 10 & $\delta$ - carene & 984 & $\mathrm{t}$ & 0.04 & 29 & Borneol & 1133 & 0.6 & 0.86 & $a, b, c$ \\
\hline 11 & $\alpha$-phellandrene & 989 & $\mathrm{t}$ & 0.08 & 30 & Terpineol & 1144 & 0.45 & 0.68 & $a, b, c$ \\
\hline 12 & $\alpha$-terpine & 996 & 0.05 & 0.07 & 31 & $\alpha$-terpineol & 1156 & 1.03 & 1.37 & $a, b, c$ \\
\hline 13 & $p$-cymene & 1005 & $\mathrm{t}$ & - & 32 & Myrtenol & 1160 & $\mathrm{t}$ & 0.07 & $a, b, c$ \\
\hline 14 & Limonene & 1006 & - & $\mathrm{t}$ & 33 & cis-piperitol & 1163 & $\mathrm{t}$ & 0.09 & $a, b, c$ \\
\hline 15 & 1,8 cineole & 1017 & 15.76 & 12.10 & 34 & Verbenone & 1170 & - & 0.08 & $a, b, c$ \\
\hline 16 & n.i & 1028 & - & 0.10 & 35 & $\beta$ - citronellol & 1177 & - & 0.06 & $a, b, c$ \\
\hline 17 & cis-sabinene hydrate & 1045 & $\mathrm{t}$ & 0.13 & 36 & trans- carveol & 1186 & $\mathrm{t}$ & 0.19 & $a, b, c$ \\
\hline 18 & Nonanone & 1061 & 0.14 & 0.04 & 37 & Citronellol & 1196 & - & 0.22 & $a, b, c$ \\
\hline 19 & Linalool & 1064 & $\mathrm{t}$ & 0.07 & 38 & cis- carveol & 1197 & 0.11 & 0.03 & $\mathrm{a}, \mathrm{b}, \mathrm{c}$ \\
\hline
\end{tabular}




\begin{tabular}{|c|c|c|c|c|c|c|c|c|c|c|}
\hline 39 & Carvone & 1209 & 0.15 & 0.02 & 59 & $\gamma$-gurjunene & 1477 & - & 0.06 & $a, b, c$ \\
\hline 40 & Isogeraniol & 1221 & 0.08 & - & 60 & $\gamma$-selinene & 1484 & - & 0.36 & $a, b, c$ \\
\hline 41 & Myrtanol & 1233 & $\mathrm{t}$ & 0.06 & 61 & Germacrene D & 1489 & 2.42 & 2.05 & $a, b, c$ \\
\hline 42 & trans-geraniol & 1239 & - & 0.10 & 62 & $\beta$-selinene & 1492 & 0.67 & 0.84 & $a, b, c$ \\
\hline 43 & Undecanone & 1241 & - & 0.13 & 63 & $\alpha$-selinene & 1501 & 4.68 & 4.78 & $a, b, c$ \\
\hline 44 & $\begin{array}{l}\text { cis - } p \text {-mentha -6,8- dien-2-ol } \\
\text { acetate }\end{array}$ & 1265 & - & 0.03 & 64 & Curzerene & 1507 & 1.07 & - & $a, b, c$ \\
\hline 45 & Myrtenyl acetate & 1274 & - & 0.01 & 65 & $\alpha$ - muurolene & 1511 & - & 0.24 & $a, b, c$ \\
\hline 46 & $\delta$ - elemene & 1276 & 1.05 & 1.03 & 66 & Bicyclogermacrene & 1513 & 0.08 & 0.08 & $a, b, c$ \\
\hline 47 & $\alpha$-copaene & 1302 & 0.29 & 0.01 & 67 & $\beta$-guaiene & 1519 & 0.34 & 0.55 & $a, b, c$ \\
\hline 48 & $\beta$ - elemene & 1310 & 4.43 & 0.01 & 68 & $\beta$ - cadinene & 1521 & - & 0.50 & $a, b, c$ \\
\hline 49 & $\alpha$-gurjunene & 1320 & 0.20 & 1.09 & 69 & $\gamma$ - cadinene & 1523 & 0.24 & - & $a, b, c$ \\
\hline 50 & $\gamma$-caryophyllene & 1420 & - & 0.42 & 70 & $\delta$ - cadinene & 1525 & 0.07 & - & $a, b, c$ \\
\hline 51 & $\beta$-caryophyllene & 1433 & - & 4.34 & 71 & Himachalene & 1532 & - & 0.43 & $a, b, c$ \\
\hline 52 & trans-caryophyllene & 1436 & 0.05 & - & 72 & Selina 3,7 diene & 1535 & 0.08 & 0.08 & $a, b, c$ \\
\hline 53 & $\gamma$ - elemene & 1446 & 1.12 & 0.05 & 73 & Germacrene B & 1540 & 0.94 & 0.27 & $a, b, c$ \\
\hline 54 & $\alpha$-guaiene & 1450 & 0.33 & 0.62 & 74 & Aristolene & 1545 & - & 0.17 & $a, b, c$ \\
\hline 55 & Aromadrendene & 1457 & 0.28 & 0.06 & 75 & Longifolene & 1547 & - & 0.94 & $a, b, c$ \\
\hline 56 & $\alpha$-humulene & 1461 & 0.18 & 0.32 & 76 & Sphatulenol & 1552 & 0.15 & 0.24 & $a, b, c$ \\
\hline 57 & trans $\beta$-farnesene & 1470 & 3.14 & 3.06 & 77 & Caryophyllene oxide & 1555 & 0.12 & 0.23 & $a, b, c$ \\
\hline 58 & Allo aromadrendene & 1471 & 0.30 & $\mathrm{t}$ & 78 & $\alpha$ - copaene- 8 ol & 1564 & - & 0.34 & $\mathrm{a}, \mathrm{b}, \mathrm{c}$ \\
\hline
\end{tabular}




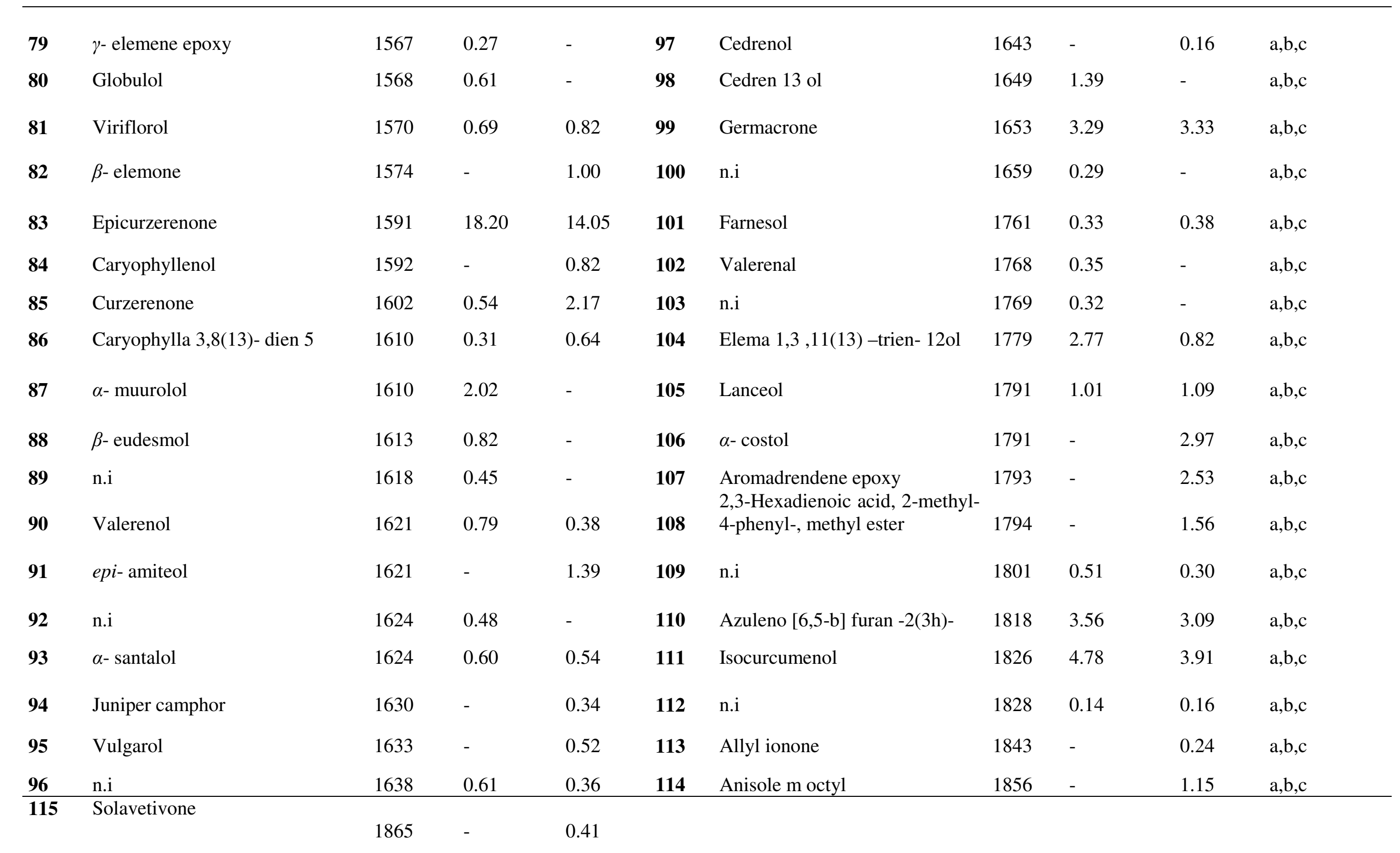


2,3-Hexadienoic acid, 2-methyl-

\begin{tabular}{lllll}
$\mathbf{1 1 6}$ & 4-phenyl-, methyl ester & 1876 & - & 0.10 \\
$\mathbf{1 1 7}$ & Iso- $\alpha$-cedren 14,15 dial & 1879 & - & 0.20 \\
$\mathbf{1 1 8}$ & n.i & 1888 & - & 0.22 \\
$\mathbf{1 1 9}$ & Isovelleral & 1895 & 0.70 & 0.29 \\
$\mathbf{1 2 0}$ & n.i & 1909 & - & 0.86 \\
$\mathbf{1 2 1}$ & Eudesma 1,4 dien -12 ol & 1878 & - & 0.08 \\
$\mathbf{1 2 2}$ & Cembrene & 1987 & $\mathrm{t}$ & 0.05 \\
$\mathbf{1 2 3}$ & 2-(Fench-2-yl) fenchane & 2917 & - & 0.04 \\
& Total Identified & & $\mathbf{9 5 . 7 7}$ & $\mathbf{9 8 . 0 0}$ \\
\cline { 2 - 4 } & Hydrocarbons Monoterpenes & & 4.63 & 4.95 \\
& Oxygenated Monoterpenes & & 25.74 & 24.57 \\
& Hydrocarbon Sesquiterpenes & & 21.96 & 22.36 \\
& Oxygenated Sesquiterpenes & & 43.30 & 43.89 \\
& Oxygenated Diterpenes & & 0.00 & 0.09 \\
Others compounds & & 0.14 & 2.14
\end{tabular}

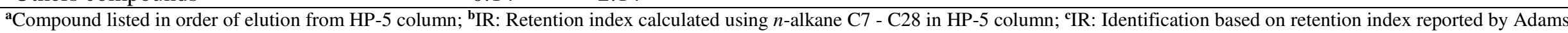
(2012) and identification based on comparison of mass spectra using NIST 11.0 library; Relative area $(\%)$ : percentage of the area occupied by the compounds in the chromatogram; $\mathrm{t}=$ trace; $\mathrm{n} . \mathrm{i}=$ not identified; (-): absent. 
Bioinsecticide potential of...

According to the data in Table 1, the rhizome EO from the dormancy period presented 120 compounds, and from the budding period 119 compounds. According to Figure 1 and Table 1, the predominant class was oxygenated Sesquiterpenes $(43.30 \%$ and $43.89 \%$ ), followed by oxygenated Monoterpenes $(25.74 \%$ and $24.57 \%)$ and hydrocarbon sesquiterpenes (21.96\% and $22.36 \%)$, respectively. In Figure 2, grouping by PCA was done and major compounds were identified in
OLIVEIRA, H. L. M. et al.

EO in dormancy and budding. Three of these compounds presented a greater mass flow distancing : epicurzerenone with $18.20 \%$ in dormancy EO and $14.05 \%$ in budding EO, 1,8cineole $(15.76 \%$ and $12.10 \%)$ and $\beta$-elemene (4.43 and $0.01 \%$ ),respectively. Moreover, it was possible to verify the formation of other group: camphor (5.61 and 5.83), curzerene $(4.68 ; 4.78)$, and velleral $(4.78 ; 3.91)$ respectively, found in both periods, at higher concentrations than $3.5 \%$.

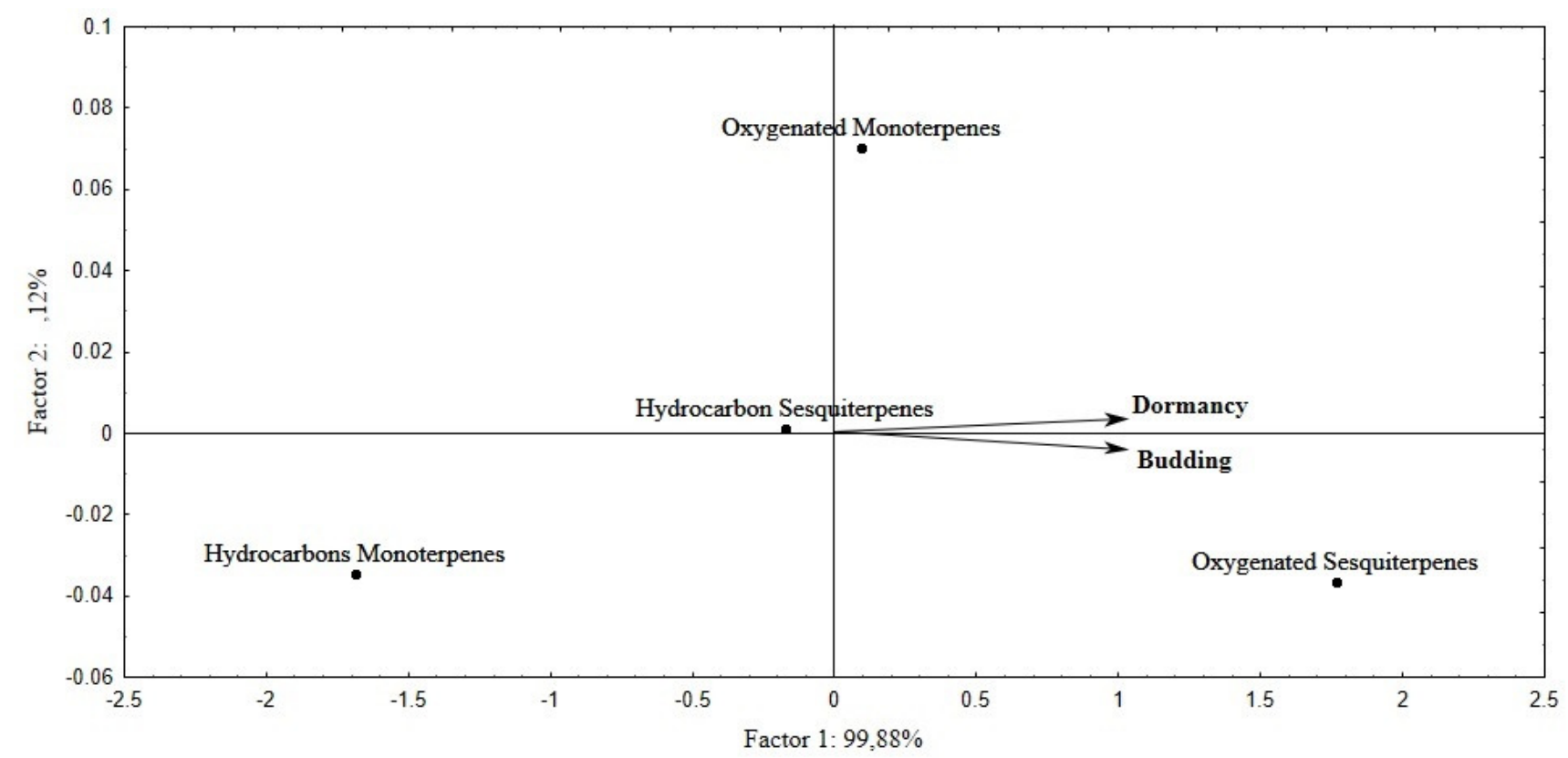

Figure 1. Biplot representing the projection of chemical classes of Curcuma zedoaria rhizome essential oil obtained during dormancy and budding periods

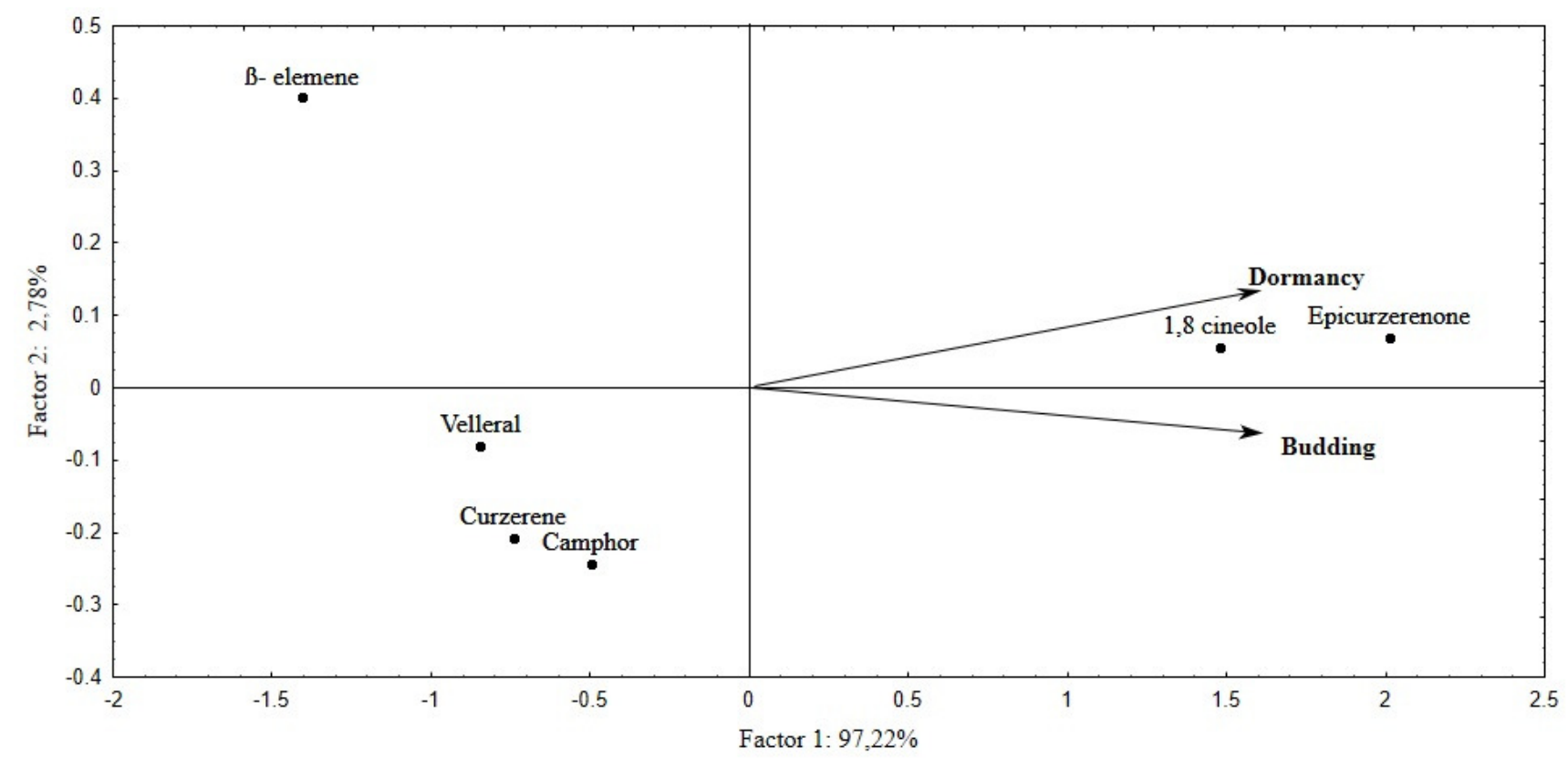

Figure 2. Biplot representing the projection of the major chemical compounds of Curcuma zedoaria rhizome essential oil obtained during dormancy and budding periods. 
The differences observed in the chemical composition in both evaluated periods (Table 1 and Figures 1 and 2) occurred in function of $C$. zedoaria vegetative cycle which is well defined in this species. It starts with the growth of vegetative sprouts (buds) in the summer. Next, growth ceasing, bud formation, senescence and leaf abscission occur in the autumn, and bud dormancy in the winter (RINNE et al., 2010; DING; NILSSON, 2016). This cycle is dynamically modulated by intrinsic environmental and hormonal factors, and according to Horvath et al. (2003), the presence of the hormones ethylene and auxin and phytochrome protein act directly on the bud dormancy stage while gibberellic acid, abscisic acid and cytokine play antagonistic roles in dormancy, regulating specific components of the cellular cycle (ANDERSON et al., 2001). Regarding the influence of intrinsic and environmental factors (photoperiod and water deficit), the vegetative and reproductive meristems of several perennial plants in temperate climate remain in a latent state without growth during the cold period of the autumn and winter, within the buds, guaranteeing an optimal protection against low and dry temperatures (RIOS et al., 2014).

Regarding the major compounds found in this experiment, they differed from the ones found by Mau et al. (2003) who evaluated the chemical composition of EO of $C$. zedoaria rhizome from China, finding epi-curzerenone (24.08\%), and curzerene $(10.36 \%)$. In a zedoaria cultivation implemented in India, Singh et al. (2002) identified 1,8 cineole $(18.50 \%)$ and $p$-cymene $(18.42 \%)$. Yonzon et al. (2005) identified 1,8 cineole (15.8\%) and $\beta$-eudesmol (10.61\%). Purkayastha et al. (2006) identified curzerenone (22.3\%), 1,8 cineole (15.9\%) and germacrone (9,0\%). Syamsir et al. (2017) also evaluated the chemical composition of zedoaria rhizomes from Malaysia and Indonesia and found camphor (17.6\% and $19.7 \%)$, zerumbone $(17.6 \%$ and $12.1 \%)$ and curzerenone (10.2\% and $7.4 \%)$, respectively.

C. zedoária EO was evaluated against $A e$. aegypti larvae and pupae by calculating the Lethal Concentrations (LCs) that are necessary to eliminate $50.0 \%\left(\mathrm{LC}_{50}\right)$ and $99.9 \%\left(\mathrm{LC}_{99.9}\right)$. The results are described in Table 2.

Table 2. Mean \pm standard deviation and confidence interval of lethal concentrations $\left(\mathrm{LC}_{50}\right.$ and $\left.\mathrm{LC}_{99.9}\right)$ of essential oil of Curcuma zedoaria rhizome collected in the dormancy and budding periods against Aedes aegypti larvae and pupae by Probitos analysis.

\begin{tabular}{|c|c|c|c|}
\hline & & $\begin{array}{c}\mathbf{L C}_{50}\left(\mathrm{mg} \mathrm{mL}^{-1}\right) \\
(\mathrm{CI})\end{array}$ & $\begin{array}{c}\mathrm{LC}_{99.9}\left(\mathrm{mg} \mathrm{mL}^{-1}\right) \\
(\mathrm{CI})\end{array}$ \\
\hline \multirow{2}{*}{$\begin{array}{l}\text { Aedes aegypti } \\
\text { Larvae }\end{array}$} & D & $\begin{array}{c}\mathbf{0 . 0 0 7 2} \mathbf{a}^{\mathbf{a}} \pm \mathbf{0 . 0 0 0 5} \\
(0.0069-0.0079)\end{array}$ & $\begin{array}{c}\mathbf{0 . 0 1 1 1}^{\mathbf{a}} \pm \mathbf{0 . 0 0 0 4} \\
(0.0109-0.0116)\end{array}$ \\
\hline & B & $\begin{array}{c}\mathbf{0 . 0 1 5 8}^{\mathbf{b}} \mathbf{\pm 0 . 0 0 2 0} \\
(0.0140-0.0179)\end{array}$ & $\begin{array}{c}\mathbf{0 . 0 8 2 1}^{\mathbf{b}} \pm \mathbf{0 . 0 0 0 8} \\
(0.0815-0.0830)\end{array}$ \\
\hline \multirow{2}{*}{ Aedes aegypti Pupae } & D & $\begin{array}{l}\mathbf{0 . 7 8 0 0}^{\mathbf{A}} \pm \mathbf{0 . 0 5 6 2} \\
(0.6825-0.7800)\end{array}$ & $\begin{array}{c}\mathbf{1 . 3 8 5 3}^{\mathbf{A}} \mathbf{\pm 0 . 0 3 7 5} \\
(1.3636-1.4287)\end{array}$ \\
\hline & B & $\begin{array}{c}\mathbf{0 . 8 6 5 4}^{\mathrm{A}} \pm \mathbf{\pm 0 . 1 1 4 4} \\
(0.7993-0.9975)\end{array}$ & $\begin{array}{c}\mathbf{2 . 6 3 5 3}^{\mathbf{B}} \pm \mathbf{0 . 1 3 4 4} \\
(2.5577-2.7906)\end{array}$ \\
\hline
\end{tabular}

LC50: concentration of the oil that killed 50\% of Aedes aegypti larvae and pupae; LC99.9.: concentration of the oil that killed $99.9 \%$ of Aedes aegypti larvae and pupae; CI: confidence interval; different letters in the same column indicate significant differences between the treatments by Duncan's Test $(\mathrm{p} \leq 0.05)$. D: period in which the plant is in dormancy; B: period in which the plant is in budding.

The essential oil of $C$. zedoaria obtained in the periods of dormancy and budding killed Ae. aegypti larvae and pupae with $\mathrm{LC}_{99.9}$ of $(0.01$ and $\left.1.38 \mathrm{mg} \mathrm{mL}^{-1}\right)$ and $\left(0.08\right.$ and $\left.2.63 \mathrm{mg} \mathrm{mL}^{-1}\right)$, respectively (Table 2 ). The greatest activity was observed in dormancy EO, corroborating the results found in the chemical analysis in which it was possible to verify that the compounds epicurzerenone, 1,8 cineole and $\beta$-elemene are found in greater amounts. From these three compounds, 1,8 cineole and $\beta$-elemene can be responsible for the larvicidal action because, similarly in $C$. zedoaria, these compounds were the major ones in EOs of some species. One of the major compounds of EO from Croton jacobinensis (Euphorbiaceae) leaves and inflorescences was 1,8 cineole $(16.90 \%)$, and when tested against $A e$. aegypti, it presented $\mathrm{LC}_{50}=0.0793 \mathrm{mg} \mathrm{mL}^{-1}$ for the leaves and $\mathrm{LC}_{50}=0.0658 \mathrm{mg} \mathrm{mL}-1$ for the inflorescences (PINTO et al., 2016). Regarding $\beta$ elemene, it is one of the major compounds of the EO of both species that were tested against $A e$. 
aegypti larvae. In Toddalia asiatica L (Rutaceae) EO, $(10.67 \%)$ of this compound was found with $\mathrm{LC}_{99}=0.293 \mathrm{mg} \mathrm{mL}^{-1}$ (MAHESWARAN et al., 2016). In Murraya exotica L (Rutaceae) EO, (7.56\%) was found with $\mathrm{LC}_{99}=0.152 \mathrm{mg} \mathrm{mL}^{-1}$ (KRISHNAMOORTHY et al., 2015). Epicurzerenone presents high antimicrobial (PRAKASH et al., 2018) and antitumor activities (SEPTANINGSIH et al., 2018); however, there have been no reports showing its larvicidal potential.

We understand that because they are major compounds of this species, it would be important to isolate them to investigate if these compounds were responsible for the mortality of Ae. aegypti larvae and pupae.
Another point to be discussed is the differentiated action of EOs against larvae and pupae. The obtained results showed greater potential against larvae because the bio compounds acted on the interaction of the larval cell wall as well as in the ingestion and absorption by their gastrointestinal tract - (PROCÓPIO et al., 2015). However, in pupae, because they do not feed themselves, the biocompound penetration was more difficult (CHAUBEY 2012; PROCÓPIO et al., 2015; PIETA et al., 2017).

The aim of our study was to verify how $C$. zedoaria EO killed larvae and pupae. Therefore, the inhibitory potential of anticholinesterase enzyme, responsible for the transmission of nervous impulses, was determined by bioautographic method, and the results are shown in Table 3.

Table 3. Evaluation of the inhibitory potential of Curcuma zedoaria rhizome essential oil on anticholinesterase enzyme.

\begin{tabular}{cccc}
\hline Concentration & \multicolumn{3}{c}{ EO } \\
\cline { 2 - 4 } m mL $^{-1}$ & Dormancy & Budding & Positive Control \\
\hline 10.00 & + & + & + \\
5.00 & + & + & + \\
2.50 & + & + & + \\
1.25 & + & + & + \\
0.625 & + & + & + \\
0.312 & + & + & + \\
0.156 & + & + & + \\
0.078 & + & - & + \\
0.039 & + & - & + \\
0.019 & - & - & + \\
0.009 & - & - & + \\
\hline
\end{tabular}

EO: essential oil; positive control: organophosphate commercial solution; $(+)$ : inhibition of acetylcholinesterase enzyme; (-): absence of inhibition of acetylcholinesterase enzyme.

The dormancy EO presented greater inhibition on the acetylcholinesterase enzyme $(0.039$ $\mathrm{mg} \mathrm{mL}^{-1}$ ) when compared to the budding period $\left(0.156 \mathrm{mg} \mathrm{mL}^{-1}\right)$, probably due to the presence of a greater amount of 1,8-cineol in dormancy EO as it presents larvicidal action already reported in the literature (LOBO et al., 2009; LIU et al., 2012; PINTO et al., 2016).

Comparing the LCs found for larvae (Table 2) and a smaller concentration that inhibited acetylcholinesterase enzyme (Table 3), it was evident that the in vitro test (bioautographic) showed lower effectiveness than the in vivo test against Ae. aegypti larvae. It can be suggested that this observed difference can be related to more than one action mechanism of the EO chemical compounds, besides the inhibition of the acetylcholinesterase enzyme. It is known that the conventional chemical larvicides, such as pyrethroids, act through different action mechanisms, which act on the neural sodium channels, interfering in their opening and closing, and extending the entry of $\mathrm{Na}^{+}$ions into the cell (SANTOS et al., 2007) while organophosphates inhibit acetylcholinesterase enzyme (BRAGA; VALLE, 2007). These results open new perspectives because our objective it to provide natural bioinsecticide that can act in synergism with conventional larvicides. 


\section{CONCLUSIONS}

The essential oil (EO) of Curcuma zedoaria rhizome obtained in the dormancy and budding periods were evaluated against Ae. aegypti larvae and pupae.

The dormancy EO presented greater potential with $\mathrm{LC}_{99.9}$ of $\left(0.01\right.$ and $\left.1.38 \mathrm{mg} \mathrm{mL}^{-1}\right)$, respectively.

The chemical analysis by GC/MS and grouping by PCA indicated the presence of epicurzerenone (18.20\%); 1,8 cineol $(15.76 \%)$ and $\beta$-elemene (4.43) with greater amount in dormancy
OLIVEIRA, H. L. M. et al.

period, indicating that these compounds can be responsible for the action against larvae and pupae.

The results were promising because they establish in which period of the vegetative cycle $C$. zedoaria EO presents greater bioinsecticide potential.

\section{ACKNOWLEDGEMENTS}

The authors thank CAPES, CNPq, Universidade Paranaense (UNIPAR) and Cesumar University.

RESUMO: Neste trabalho foi avaliado o potencial bioinseticida do óleo essencial (OE) extraído dos rizomas da espécie Curcuma zedoaria (Zingiberaceae), coletados no período de dormência (inverno) e brotação das gemas (verão). O OE foi obtido por hidrodestilação (2h) e identificado por CG/EM foi observado rendimento 0,61 $\pm 0,07$ (\%) no óleo da dormência, quando comparado no período de brotação 0,55 $\pm 0,08$ (\%). Os bioensaios sobre as larvas e pupas de Aedes aegypti foram realizados pelo teste de imersão em diferentes concentrações dos OEs, que variaram de 500,00 a $0,003 \mathrm{mg} \mathrm{mL}^{-1}(\mathrm{v} / \mathrm{v})$. Os resultados sobre as larvas e pupas indicaram uma $\mathrm{CL}_{99,9}$ de $\left(0,01\right.$ e $\left.1,38 \mathrm{mg} \mathrm{mL}^{-1}\right)$ para o OE da dormência, e $\left(0,08\right.$ e 2,63 $\left.\mathrm{mg} \mathrm{mL}^{-1}\right)$ para o OE do período de brotação, respectivamente. Indicando maior atividade do $\mathrm{OE}$ da dormência. $\mathrm{O}$ mecanismo de ação dos OEs nos dois períodos foi determinado pelo método autobiográfico avaliando o potencial inibitório sobre a enzima acetilcolinesterase. Os resultados indicaram maior inibição da enzima do OE no período de dormência $\left(0,039 \mathrm{mg} \mathrm{mL}^{-1}\right)$, quando comparado ao $\mathrm{OE}$ de brotação $\left(0,156 \mathrm{mg} \mathrm{mL}^{-1}\right)$. A análise química destacou três compostos: epicurzerenone $(18,20 \%$ e $12,10 \%)$ e 1,8 cineol $(15,76 \%$ e $14,05 \%)$ e $\beta$ - elemeno $(4,43$ e $0,01 \%)$ em maior quantidade no período de dormência quando comparado ao período de brotação, respectivamente. Esta diferença pode explicar a maior ação inseticida do OE de dormência sobre as larvas e pupas do Ae. aegypti. Os resultados são promissores, pois estabelece em qual período do ciclo vegetativo o $\mathrm{OE}$ da $C$. zedoaria apresenta maior potencial bioinseticida.

PALAVRA-CHAVE: Aedes aegypti. Anticolinesterase. 1,8-cineol. Epicurzerenone. $\beta$-Elemeno. Concentração letal (CL).

\section{REFERENCES}

ADAMS, R. P. Identification of essential oil components by gas chomatography/mass spectrometry, 4. ed. Illinois: Allured Publishing Corporation, 2012. 804p.

ANDERSON, J. V.; CHAO, W. S.; HORVAT, J. D. P. A current review on the regulation of dormancy in vegetative buds. Weed Science Society of America, v. 49, p. 581-589, 2001. https://doi.org/10.1614/00431745(2001)049[0581:RCROTR]2.0.CO;2

ANGEL, G. R.; MENON, N.; VIMALA, B.; NAMBISAN, B. Essential oil composition of eight starchy Curcuma species. Industrial Crops Products, v. 60, p. 233-238, 2014.

https://doi.org/10.1016/j.indcrop.2014.06.028

BRAGA, I. A.; VALLE, D. Aedes aegypti: inseticidas, mecanismos de ação e resistência. Epidemiologia e Serviços de Saúde, v. 16, n. 4, p. 279-293, 2007. http://dx.doi.org/10.5123/S1679-49742007000400006 
BRASIL. MINISTÉRIO DA SAÚDE. FEBRE PELO VÍRUS ZIKA: UMA REVISÃO NARRATIVA SOBRE A DOENÇA. v. 46, n. 26, 2015. Available in:

$<$ http://portalarquivos2.saude.gov.br/images/pdf/2015/agosto/26/2015-020-publica----o.pdf>. Access in: 10 nov. 2017

BRASIL. Secretaria de Vigilância em Saúde. Boletim Epidemiológico. Monitoramento dos casos de dengue, febre de chikungunya e febre pelo vírus Zika até a semana epidemiológica 5, 2018. Ministério da Saúde: Brasília, v. 49, n. 14, p. 1-13, 2018. Available in:

http://portalarquivos2.saude.gov.br/images/pdf/2018/abril/06/2018-012.pdf: Access in: 08 abr. 2018.

BUSATO, M. A.; CORRALO, V. S.; GUARDA, C.; ZULIAN, V.; LUTINSKI, J. A.; BORDIN, S. M. S. Evolução da infestação por Aedes aegypti (Diptera: Culicidae) nos municípios do oeste do estado de Santa Catarina. Revista de Saúde Pública, Florianópolis, v. 7, n. 2, p. 107-118, 2014.

CAMARGO, M. F.; SANTOS, H. A.; OLIVEIRA, S. W.A.; NEWDVAR, A.; ALVES, N. B. R.; ISAC, E. Avaliação da ação residual do larvicida temephos sobre o Aedes aegypti (Diptera, Culicidae) em diferentes tipos de recipientes. Revista de Patologia Tropical, v. 27, n. 1, p. 65-70, 1998.

http://doi.org/10.5216rpt.v27i1.17197

CARVALHO, A. F. U.; CARVALHO, U.; MELO, V. M. M.; CRAVEIRO, A. A.; MACHADO, M. I. L.; BANTIM, M. B.; RABELO, E. F. Larvicidal Activity of the Essential Oil from Lippia sidoides Cham. against Aedes aegypti Linn. Memórias do Instituto Oswaldo Cruz, v. 98, n. 4, p. 569-571, 2003. http://dx.doi.org/10.1590/S0074-02762003000400027

CAVALCA, P. M. A.; LOLIS, M. I. G. A.; REIS B.; BONATO CM. Homeopathic and larvicide effect of Eucalyptus cinerea essential oil against Aedes aegypti. Brazilian Archives of Biology and Technology, v. 53, n. 4, p. 835-843, 2010. http://dx.doi.org/10.1590/S1516-89132010000400012

CHAUBEY, M. K. Acute, lethal and synergistic effects of some terpenes against Tribolium castaneum Herbst (Coleptera: Tenebrionidae). Ecologia Balkanica, v.4, n.1, p. 53-62, 2012

COLLINS, C. H.; BRAGA, G. L.; BONATO, P. S. Introdução a Metodologia Cromatográfica. 6· ed. Campinas: Unicampi, 1997.

COSMOSKI, A. C. O. F.; ROEL, A. R.; PORTO, K. R. de A.; MATIAS, R.; HONER, M. R.; MOTTI, P. R. Phytochemistry and larvicidal activity of Spermacoce latifolia AUBL. (Rubiaceae) in the control of Aedes aegypti L. (Culicidae). Bioscience Journal, v. 31, n. 5, p. 1512-1518, 2015. http://dx.doi.org/10.14393/BJv31n5a2015-26333

COSTA, J. G. M.; RODRIGUES, F. F. G.; ANGÉliCO, E. C.; SILVA, M. R.; MOTA, M. L.; SANTOS, N. K. A.; CARDOSO, A. L. H.; LEMOS, T. L. G. Chemical-biological study of the essential oils of Hyptis martiusii, Lippia sidóides and Syzigium aromaticum against larvae of Aedes aegypti and Culex. Revista Brasileira de Farmacognosia, v. 15, n. 4, p. 304-309, 2005. http://dx.doi.org/10.1590/S0102-695X2005000400008

DING, J.; NILSSON, O. Molecular regulation of phenology in trees - because the seasons they are achangin'. Current Opinion in Plant Biology, v. 29, p. 73-79, 2016. https://doi.org/10.1016/j.pbi.2015.11.007

GOUINGUENÉ, S. P.; TURLINGS, T. C. J. The effects of abiotic factors on induced volatile emissions in corn plants. Plant Physiology, v. 129, p. 1296-1307, 2002.

https://doi.org/10.1104/pp.001941

GUENTHER, E. The Essential Oils. 3.ed. New York: D. Van Nostrand, 1950. v. 4.

HAIR, J. F; ANDERSON, R. E; TATHAM, R. L; BLACK, W., HAIR, J. Análise multivariada de dados. 5. ed. Porto Alegre: Bookman, 2005. 
HORVATH, D. P.; JAMES, V. A.; CHAO, S.W.; MICHAEL, E. F. Knowing when to grow: signals regulating bud dormancy. Trends in Plant Science, v. 8, n. 11, p. 534-540, 2003.

https://doi.org/10.1016/j.tplants.2003.09.013

KRISHNAMOORTHY, S.; CHANDRASEKARAN, M.; RAJ, G. A.; JAYARAMAN, M.;

VENKATESALU, V. Identification of chemical constituents and larvicidal activity of essential oil from Murraya exotica L. (Rutaceae) against Aedes aegypti, Anopheles stephensiand Culex quinquefasciatus (Diptera: Culicidae). Parasitology Research, v. 114, n. 5, p. 1839-1845, 2015. https://doi/abs/10.1007/s00436-015-4370-x

LAI, E. Y.; CHYAU, C. C.; MAU, J. L.; CHEM, C. C.; LAI, Y. J.; SHIH, F.C.; LIN, L. L. Antimicrobial Activity and Cytotoxicity of the Essential Oil of Curcuma zedoaria. The American Journal of Chinese Medicine, v. 32, n. 2, p. 281- 290, 2004. https://doi/abs/10.1142/S0192415X0400193X

LIU, Z. L.; ZHAO, N. N.; LIU, C. M.; ZHOU, L.; DU, S. S. Identification of insecticidal constituents of the essential oil of Curcuma wenyujin rhizomes against Liposcelis bostrychophila Badonnel. Molecules, v. 17, p. 12049-12060, 2012. http://dx.doi.org/10.3390/molecules171012049

LOBO, R.; PRABU, K. S.; SHIRWAIKAR A.; SHIRWAIKARB A. Curcuma zedoaria Rosc. (white turmeric): a review of its chemical, pharmacological and ethnomedicinal properties. Journal of Pharmacy and Pharmacology, v. 61, n. 1, p. 13-21, 2009. https://doi/abs/10.1211/jpp/61.01.0003

LORENZI, H. Árvores brasileiras: Manual de identificação e cultivo de plantas arbóreas nativas do Brasil, 4. ed. São Paulo: Instituto Plantarum de Estudos da Flora Ltda., 2002. 368 p.

MAHESWARAN, R.; SUKUMARAN, S.; NATTUDURAI, G.; IGNACIMUTHU, S. Bioefficacy of essential oil from Toddalia asiatica (L.) Lam. against dengue vector mosquitoes Aedes aegypti L. and Aedes albopictus Skuse. Indian Journal of Natural Products and Resources, v. 7, n. 3, p. 245- 251, 2016.

MARSTON, A.; KISSLING, J.; HOSTETTMANN, K. A. A rapid TLC bioautography method for the detection of acetylcholinesterase and butyrylcholinesterase inhibitors in plants. Phytochemical Analysis, v. 13, p. 51-54, 2002. http://dx.doi.org/10.1002/pca.623

MAU, J.; LAIB, E.; WANG, N.; CHEN, C.; CHANG, C.; CHYAU, C. Composition and antioxidant activity of the essential oil from Curcuma zedoaria. Food Chemistry, v. 82, n. 4, p. 583-591, 2003.

https://doi.org/10.1016/S0308-8146(03)00014-1

MOITA NETO, J. M.; MOITA, G. C. An introduction analysis exploratory multivariate date. Química Nova, n, 21, v. 4, p. 467-469, 1998.

MORAIS, L. A. S. Influência dos fatores abióticos na composição química dos óleos essenciais. Horticultura Brasileira.v. 27. n. 2. p. 4050- 4063, 2009.

NICOLAU, E. S.; ALVES, P. B.; NOGUEIRA, P. C. L. Atividade inseticida de óleo essenciais de Pelargonium graveolens l'Herit E Lippia alba (Mill) N. E. Brown sobre Spodeptera frugiperda (J.E. Smith). Química Nova, v. 36, n. 9, p. 1391-1394, 2013. https://doi.org/10.1590/S0100-40422013000900020

OLIVEIRA, E. da S.; BIAZOTO, C. D. dos S. Breeding sites distribution of Aedes aegypti (linna.us, 1762) and Aedes albopictus (skuse, 1894) (diptera: cullicidae) in the municipality of assis chateaubriand, state of Paraná, Brazil. Bioscience Journal, v. 28, n. 6, p. 1051-1060, 2012. 
PIETA, L.; ESCUDERO, F. L. G.; JACOBUS, A. P.; CHEIRAN, K. P.; GROSS, J.; MOYA, M. L. E.; SOARES, G. L. G.; MARGIS, R.; FRAZZON, A. P. G AND FRAZZON J. Comparative transcriptomic analysis of Listeria monocytogenes reveals upregulation of stress genes and downregulation of virulence genes in response to essential oil extracted from Baccharis psidioides. Annals of Microbiology, v. 67, p. 479-490, 2017.

PINTO, C. C. C.; MENEZES, J.; SIQUEIRA, S. M. C.; MELO, D. S.; FEITOSA, C. R. S.; SANTOS, H. S. Chemical Composition and larvicidal activity against Aedes aegypti of essential oils from Croton jacobinenesis Baill. Boletin Latinoamericano y del Caribe de Plantas Medicinales y Aromáticas. v. 15, n. 2, p. 122 - 127 , 2016.

PRAKASH, B.; KUJUR, A.; YADAV, A.; KUMAR, A.; SINGH, P. P.; DUBEY, N. K. Nanoencapsulation: An efficient technology to boost the antimicrobial potential of plant essential oils in food system. Food Control. In press, 2018. https://doi.org/10.1016/j.foodcont.2018.01.018

PROCÓPIO, T. F., FERNANDES, K. M., PONTUAL, E. V., XIMENES, R. M., OLIVEIRA, A. R. C., DE, SOUZA, C. S., AMMA, MELO, DMAF, NAVARRO, PMG, PAIVA, MARTINS, G. F., NAPOLEÃO, T. H. Schinus terebinthifolius leaf extract causes midgut damage, interfering with survival and development of Aedes aegypti larvae. Plos One. n. 10, v. 5, p. 1-19, 2015. http://dx.doi.org/10.1371/ journal.pone.0126612.

PURKAYASTHA, J.; NATH, S. C.; KLINKBY, N. Essential oil of the rhizome of Curcuma zedoaria (Christm.) Rosc. native to Northeast India. Journal of Essential Oil Research, v. 18, n. 2, p. 154155, 2006. https://doi.org/10.1080/10412905.2006.9699050

RINNE, P. L. H.; WELLING, A.; VAN DER SCHOOT, C. Perennial Life Style of Populus: Dormancy Cycling and Overwintering. In: Jasson S, Bhalerao R, Groover A. eds. Genetics and Genomics of Populus. Ed Springer, p. 171-200, 2010. https://doi.org/10.1007/978-1-4419-1541-2_9

RIOS, G.; LEIDA, C.; CONEJERO, A.; BADENES, M. L. Epigenetic regulation of bud dormancy events in perennial plants. Frontiers in Plant Science, v. 5, p. 1-6, 2014. https://doi.org/10.3389/fpls.2014.00247

SANTOS, M. A. T.; AREAS, M. A.; REYES, F. G. R. Piretróides - uma visão geral. Alimentos e Nutrição, v. 18, n. 3, p. 339-349, 2007.

SANTOS, S. R.; SILVA, V. B.; MELO, M. A.; BARBOSA, J. D.; SANTOS, R. L.; SOUSA, D. P.; SOCRATES, C. H.; CAVALCANTI. Toxic effects on and structure-toxicity relationships of phenylpropanoids, terpenes, and related compounds in Aedes aegypti larvae. Vector Borne Zoonotic Dis, v. 10, n. 10, p. 1049-54, 2010. https://doi.org/10.1089/vbz.2009.0158

SEPTANINGSIH, D. A.; DARUSMAN, L. K.; AFENDI, F. M.; HERYANTO, R. Liquid Chromatography Mass Spectrometry (LC-MS) Fingerprint Combined with Chemometrics for Identification of Metabolites Content and Biological Activities of Curcuma aeruginosa. Indones. Journal of Chemitry, n. 18, v. 1, p. 43 52, 2018. https://doi.org/10.22146/ijc.25456.

SINGH, G.; SINGH, O. P.; MAURYA, S. Chemical and biocidal investigations on essential oils of some Indian Curcuma species. Progress in Crystal Growth and Characterization of Materials, v. 45, n. 1, p. 75 81, 2002. https://doi.org/10.1016/S0960-8974(02)00030-X

SMITH, L. B.; KASAI, S.; SCOTT, J. G. Pyrethroid resistance in Aedes aegypti and Aedes albopictus: Important mosquito vectors of human diseases. Pesticide Biochemistry and Physiology, v. 133, p. 1-13, 2016. https://doi.org/10.1016/j.pestbp.2016.03.005.

STATSOFT INC, 2018. Statistica for Windows (Computer Program Manual). (Accessed July 17 2001). http://www.statsoft.com/. 
SYAMSIR, R. D. Chemical Constituents and Evaluation of Cytotoxic Activities of Curcuma zedoaria (Christm.) Roscoe Oils from Malaysia and Indonesia. Journaul of essential oil bearing plants, v. 20, p. 972982, 2017. https://doi.org/10.1080/0972060X.2017.1362997

WORLD HEALTH ORGANIZATION (WHO). Mosquito control: can it stop Zika at source? 2016. Available in: <http://www.who.int/emergencies/zikavirus/articles/mosquitocontrol/en/>: access in: 23.10.17.

YANG, Z. D; ZHANG, X.; DUAN, D. Z; SONG, Z.; Yang, M. J.; LI, S. Modifiel TLC bioautographie method for screening acetylcholinesterase inhibitors from plant extracts. Journal of Separation Science, v. 32, p. 3257-3259, 2009. https://doi.org/10.1002/jssc.200900266

YONZON, M.; LEE, D. J.; YOKOCHI, T.; KAANO, Y.; NA-KAHARA, T. Antimicrobial activities of essential oils of Nepal. - Journal of Essential Oil Research, v. 17, n. 1, p. 107-111, 2005.

https://doi.org/10.1080/10412905.2005.9698846 